\title{
Rectus sheath haematoma due to drug-drug interaction
}

\author{
Nikita Theophilus, Ghassan Bachuwa
}

Internal Medicine, Hurley Medical Center, Flint, Michigan, USA

\section{Correspondence to} Dr Ghassan Bachuwa; gbachuw2@hurleymc.com

Accepted 7 May 2021
Check for updates

(C) BMJ Publishing Group Limited 2021. No commercial re-use. See rights and permissions. Published by BMJ.

To cite: Theophilus $\mathrm{N}$, Bachuwa G. BMJ Case Rep 2021;14:e242751 doi:10.1136/bcr-2021242751

\section{DESCRIPTION}

A 68-year-old man presented with complaints of abdominal pain. A week earlier, he had influenzalike symptoms with fever as high as $40^{\circ} \mathrm{C}$, chills and persistent cough. He was prescribed azithromycin $250 \mathrm{mg}$ daily for 5 days. Two days after being started on azithromycin, he experienced abdominal pain. He described it as a shearing pain. It was initially restricted towards the right mid-abdomen, non-radiating and exacerbated on coughing. The pain gradually increased in intensity over the next 2 days and involved bilateral lower quadrants. Due to worsening abdominal pain, he sorted medical attention. He was a known case of hypertension, coronary artery disease and atrial fibrillation on aspirin $81 \mathrm{mg}$ and apixaban $5 \mathrm{mg}$ two times a day. On examination, he was haemodynamically stable. Overlying skin changes were absent, but multiple swellings were palpable over the abdominal wall. Ultrasound of the abdomen showed a rectus sheath haematoma approximately $9.0 \mathrm{~mm} \times 45.6 \mathrm{~mm}$ in size (figure 1). Apixaban dose was lowered to half for 1 week, after which he resumed his original dose. Over the next 4 weeks, the pain and swelling gradually subsided.

Apixaban which is a novel oral anticoagulant is a direct factor $\mathrm{Xa}$ inhibitor (figure 2). Out of several indications, the one pertinent to this case is stroke prevention in non-valvular atrial fibrillation. Apixaban is primarily metabolised by cytochrome p450(CYP)3A4. A reduction to $50 \%$ of the prescribed dose of apixaban is recommended in patients receiving a strong cytochrome p450(CYP)3A4 inhibitor. ${ }^{1}$ Although azithromycin is considered a mild inhibitor and the present literature does not recommend a dose adjustment, it poses as a risk factor for

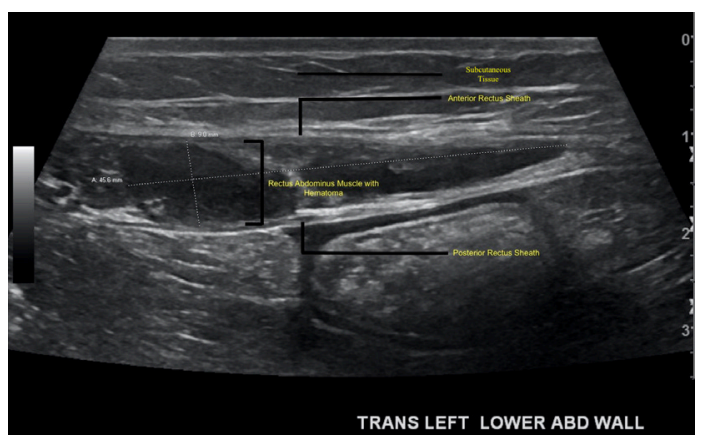

Figure 1 Transverse plane ultrasound of the left lower abdominal wall showing a cystic mass with internal septation, measuring approximately $9.0 \mathrm{~mm} \times 45.6 \mathrm{~mm}$, suggestive of rectus sheath haematoma.

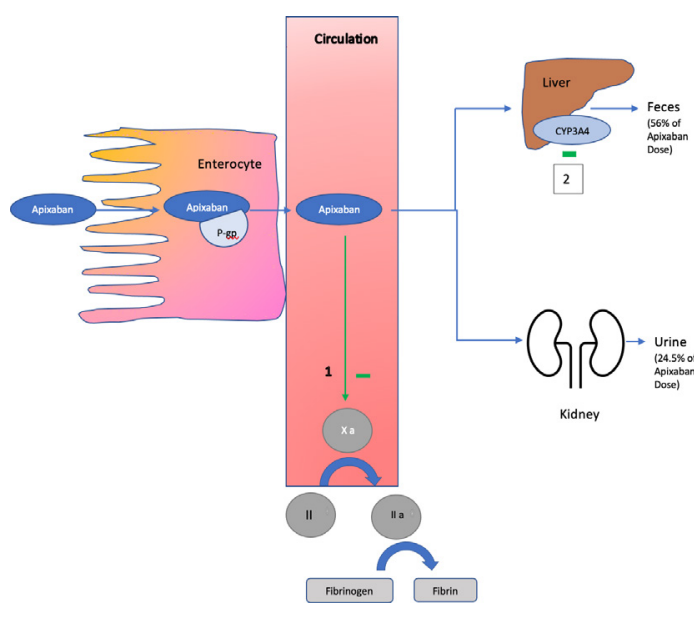

Figure 2 Apixaban acts as a substrate for permeability glycoprotein (P-gp) and cytochrome 450 enzymes. Cytochrome 3A4 (CYP3A4) is the predominant cytochrome (CYP) enzyme that metabolises apixaban. Inducers and inhibitors of P-gp and cytochrome P450 enzymes can in turn decrease or increase the level of apixaban in circulation. $\mathrm{Xa}$, activated factor $\mathrm{X}$; II, factor II; Ila, activated factor II. ${ }^{5} 1$-Apixaban inhibits free and clot-bound factor Xa. ${ }^{5}$-Cytochrome P450 enzyme inhibitors decrease the rate of metabolism and can increase apixaban levels in circulation. ${ }^{1}$ (This picture has been created and edited by Nikita Theophilus, MD, and Brandon Flues, PharmD.)

the development of a rectus sheath haematoma (RSH) in our case. ${ }^{2}$

RSH should be suspected in patients on anticoagulants who present with abdominal pain and abdominal swellings in the setting of severe cough. A diagnosis can be made based on abdominopelvic CT or ultrasound. Management depends on the patient's clinical status. Most of the patients respond to supportive medical care, which includes volume resuscitation and symptomatic management. Refractory cases may require angiographic

\section{Learning points}

- Rectal sheath haematoma (RSH) should be suspected in patients on anticoagulants who present with abdominal pain following persistent cough.

- A diagnosis of RSH can be made by ultrasound or CT.

- Concomitant administration of factor Xa inhibitors and cytochrome p450(CYP)3A4 inhibitors increases the risk of bleeding. 
embolisation or surgical intervention. ${ }^{3}$ Oral anticoagulation can be restarted after stabilisation of haemoglobin and evidence of a stable or resolving haematoma. Resuming oral anticoagulation after 4 days was found to be safe in most of the patients, with thrombotic complications outnumbering bleeding episodes in patients where anticoagulation was withheld for too long after being diagnosed with $\mathrm{RSH}^{4}{ }^{4}$ The possibility of drug interactions should always be assessed when prescribing medications to patients on anticoagulants as bleeding episodes may prove to be fatal.

Contributors NT and GB take full responsibility of the work. They conducted a literature search and helped in formatting and drafting out the article. Access to data and the final decision made to publish this case report was a combined decision.

Funding The authors have not declared a specific grant for this research from any funding agency in the public, commercial or not-for-profit sectors.

Disclaimer Case reports provide a valuable learning resource for the scientific community and can indicate areas of interest for future research. They should not be used in isolation to guide treatment choices or public health policy.
Competing interests None declared.

Patient consent for publication Obtained.

Provenance and peer review Not commissioned; externally peer reviewed.

\section{ORCID iD}

Ghassan Bachuwa http://orcid.org/0000-0001-8414-0067

\section{REFERENCES}

1 Eliquis (apixaban) [prescribing information]. New York, NY: Pfizer Inc 2016.

2 Hill K, Sucha E, Rhodes E, et al. Risk of hospitalization with hemorrhage among older adults taking clarithromycin vs azithromycin and direct oral anticoagulants. JAMA Intern Med 2020;180:1052-60.

3 Sunga KL, Bellolio MF, Gilmore RM, et al. Spontaneous retroperitoneal hematoma: etiology, characteristics, management, and outcome. J Emerg Med 2012;43:e157-61

4 Kunkala MR, Kehl J, Zielinski MD. Spontaneous rectus sheath hematomas: when to restart anticoagulation? World J Surg 2013;37:2555-9.

5 Byon W, Garonzik S, Boyd RA, et al. Apixaban: a clinical pharmacokinetic and pharmacodynamic review. Clin Pharmacokinet 2019;58:1265-79.

Copyright 2021 BMJ Publishing Group. All rights reserved. For permission to reuse any of this content visit https://www.bmj.com/company/products-services/rights-and-licensing/permissions/

BMJ Case Report Fellows may re-use this article for personal use and teaching without any further permission.

Become a Fellow of BMJ Case Reports today and you can:

- Submit as many cases as you like

- Enjoy fast sympathetic peer review and rapid publication of accepted articles

- Access all the published articles

- Re-use any of the published material for personal use and teaching without further permission

Customer Service

If you have any further queries about your subscription, please contact our customer services team on +44 (0) 2071111105 or via email at support@bmj.com.

Visit casereports.bmj.com for more articles like this and to become a Fellow 